\title{
Comparison of enzyme activities linked to acid-base regulation in a deep-sea and a sublittoral decapod crab species
}

\author{
Eric F. Pane ${ }^{1, *}$, Martin Grosell ${ }^{2}$, James P. Barry ${ }^{1}$ \\ ${ }^{1}$ Monterey Bay Aquarium Research Institute, 7700 Sandholdt Rd., Moss Landing, California 95039, USA \\ ${ }^{2}$ Rosenstiel School of Marine and Atmospheric Science, 4600 Rickenbacker Causeway, Miami, Florida 33149, USA
}

\begin{abstract}
When compared to the sublittoral Dungeness crab Cancer magister, the deep-sea Tanner crab Chionoecetes tanneri exhibited lower activities of enzymes involved in some of the processes essential for efficient acid-base regulation. Tissue enzymatic activities were compared between Dungeness crabs held in normoxia and Tanner crabs held in hypoxia - both treatments mimicking typical habitat oxygen levels. In the posterior gill, activities of all forms of ATPase and carbonic anhydrase (CA) were approximately 2- to 13.2-fold lower in Tanner crabs than in Dungeness crabs. CA activity in the heart and white muscle was also significantly lower in hypoxic deep-sea Tanner crabs, while ATPase activity in these 2 tissues was similar between the 2 treatments. Diagnostically, enzymatic activities were compared when both species were held in normoxic seawater, with additional significant differences found in specific white muscle ATPase fractions (amiloride- and N-ethylemaleimide [NEM]-sensitive ATPases) and tissue buffering ( $\beta$ ) capacity. When both species were acclimated to normoxia, $C$. tanneri exhibited mass specific rates of oxygen consumption significantly lower (4.5-fold) than C. magister. Under short-term, strongly hypercapnic conditions $(1 \%$ $\mathrm{CO}_{2}$ ), the Dungeness crab displayed reduced (30 to 40\%) branchial ATPase activities, while enzymatic activities in the Tanner crab gill, muscle and heart were refractive to short-term (24 h) hypercapnia, suggesting a minimal ability to tune branchial function to changing environmental conditions. These results support our hypothesis that the deep-sea Tanner crab has a reduced capacity for active transport of acid-base relevant ions, particularly at the gill, and is therefore at a marked disadvantage with respect to iono- and acid-base regulatory capacity. These results add to a growing database documenting the limited ability of deep-sea megafauna to compensate for internal acid-base disruptions associated with introduction of anthropogenic $\mathrm{CO}_{2}$ into the deep sea.
\end{abstract}

KEY WORDS: $\mathrm{CO}_{2} \cdot$ Deep sea $\cdot$ Physiology $\cdot$ Decapod crustacean $\cdot$ Acid-base regulation Resale or republication not permitted without written consent of the publisher

\section{INTRODUCTION}

Direct, large-scale sequestration of carbon dioxide $\left(\mathrm{CO}_{2}\right)$ into the deep sea has been advanced as a possible solution to rising atmospheric $\mathrm{CO}_{2}$ levels (Marchetti 1977, 1979). Additionally, the chronic absorption of atmospheric $\mathrm{CO}_{2}$ by surface ocean waters coupled with ocean mixing is causing a significant increase in anthropogenic $\mathrm{CO}_{2}$ in the deep-sea (Feely et al. 2004), with projected large increases in the future.

Caution has been advised regarding the possible detrimental effects of anthropogenically induced deep- sea hypercapnia on characteristically hypometabolic deep-sea fauna (Seibel \& Walsh 2001, Pörtner et al. 2004). Deep-sea fauna are also predicted to be highly sensitive to hypercapnia due to long-term adaptation to a naturally invariant physio-chemical environment (Gage \& Tyler 1991, Kennett \& Ingram 1995, Pörtner et al. 2004).

In a companion paper (Pane \& Barry 2007), we showed that a deep-sea decapod crustacean, the grooved Tanner crab Chionoecetes tanneri, was more sensitive to short-term, severe hypercapnia than the sublittoral Pacific Dungeness crab Cancer magister. 
During $24 \mathrm{~h}$ of high-level hypercapnia, C. tanneri made no compensation for a 0.4 unit reduction in extracellular (hemolymph) $\mathrm{pH}$. In contrast, C. magister completely restored extracellular $\mathrm{pH}$ to normocapnic levels during the same hypercapnic challenge (Pane \& Barry 2007).

Since the metabolically costly process of acid-base regulation (particularly during hypercapnic challenge) requires extensive ion transport capacity (Ahearn et al. 1999), we have hypothesized that the limited acidbase regulatory function exhibited by Chionoecetes tanneri is a function of reduced capacity to actively transport acid-base relevant ions across membranes, particularly the branchial epithelium. A previous report comparing 2 species of deep-sea crabs of the genus Chaceon with the sublittoral Callinectes sapidus concluded that activities of specific metabolic enzymes were generally much lower in the deep-sea decapod species (Walsh \& Henry 1990).

The current report continues the comparison between Chionoecetes tanneri and Cancer magister (see Pane \& Barry 2007) to test the hypothesis that activities of acid-base relevant enzymes are lower in deep-sea decapod species. We have compared Dungeness crabs held in normoxic seawater to Tanner crabs held in hypoxic seawater. These conditions best mimic typical in situ oxygen levels, giving the more physiologically relevant comparison. We have also eliminated oxygen as a variable and compared enzymatic activities from individuals of both species held in normoxic seawater. Enzymatic rates presented include total ATPase, $\mathrm{Na}^{+}-\mathrm{K}^{+}$-ATPase, P-type (membrane-bound and N-ethylemaleimide [NEM]) ATPases, amiloridesensitive ATPases, and carbonic anhydrase. The relevant acid-base impact of the ATPases we selected involves general creation and maintenance of ion (particularly $\mathrm{Na}^{+}$) gradients necessary for efficient acidbase regulation (Henry \& Wheatly 1992, Wheatly \& Henry 1992, Pequeux 1995). Carbonic anhydrase participates directly in acid-base regulation by catalyzing the reversible hydration of $\mathrm{CO}_{2}$ to form carbonic acid and subsequently bicarbonate ions and protons (Henry \& Cameron 1983, Henry \& Wheatly 1992).

Additionally, whole animal oxygen uptake rates were used to assess the extent of hypometabolism in the deep-sea Chionoecetes tanneri, and in vitro tissue buffering capacity was measured to further compare acid-base regulatory capacities between the 2 crab species. To evaluate any direct effect of elevated $\mathrm{CO}_{2}$ on acid-base regulatory capacity, crabs of both species were exposed to high levels of $\mathrm{CO}_{2}$ in short-term $(24 \mathrm{~h})$ experiments. The merits of using the 2 species, C. tanneri and Cancer magister, in such a comparative approach are outlined in Pane \& Barry (2007).

\section{MATERIALS AND METHODS}

Animal collection and holding. A detailed account of collection and laboratory holding of the deep-sea decapod crab Chionoecetes tanneri can be found in Pane \& Barry (2007). Briefly, C. tanneri of both sexes (200 to $800 \mathrm{~g}$ ) were collected by remote operated vehicle from the seafloor at depths of 950 to $1050 \mathrm{~m}$ within Monterey Canyon (see Fig. 1 in Pane \& Barry 2007). Crabs were transferred to the laboratory and held in a recirculated seawater system in darkened chambers at $3^{\circ} \mathrm{C}$, a pH of $7.85 \pm 0.10$, and a salinity of $35 \pm 1$. Laboratory holding and experimentation were conducted under normobaric conditions. Oxygen levels were either $90 \pm 5 \%$ saturation (normoxia $\approx 350 \mu \mathrm{M}$ ), or $10 \pm 5 \%$ saturation (hypoxia $\approx 40 \mu \mathrm{M}$ ). The hypoxic treatment mimicked in situ oxygen levels typical of the oxygen minimum zone at depths between roughly 400 and $1200 \mathrm{~m}$ off the California coast (Childress 1995).

Pacific Dungeness crabs Cancer magister of both sexes $(500$ to $900 \mathrm{~g}$ ) were captured from 30 to $40 \mathrm{~m}$ depth by local fishermen using baited traps. Crabs were transferred to the laboratory and held in flowing seawater at $10 \pm 1^{\circ} \mathrm{C}$, with a $\mathrm{pH}$ of $7.90 \pm 0.10$, salinity of $35 \pm 1$, and an oxygen saturation of $90 \pm 5 \%$, under a $12 \mathrm{~h}$ light:12 h dark photoperiod. During the holding period, all crabs were fed to satiation with chopped squid. Food was withheld $48 \mathrm{~h}$ prior to, and throughout, all $24 \mathrm{~h}$ hypercapnic exposures. Experiments starving 2 other species of deep-sea crab, Geryon longipes and Bythograea thermydron, for $34 \mathrm{~d}$ have shown no effect of starvation on the metabolic function of muscle tissue (Company et al. 2008).

Hypercapnic exposure. Short-term hypercapnia was accomplished via $24 \mathrm{~h}$ exposures to flowing seawater equilibrated with $1 \% \mathrm{CO}_{2}$ delivered from calibrated gas cylinders (Airgas) containing either 1\% $\mathrm{CO}_{2}, 3 \% \mathrm{O}_{2}$, balance $\mathrm{N}_{2}$ (hypoxia); or $1 \% \mathrm{CO}_{2}, 20 \%$ $\mathrm{O}_{2}$, balance $\mathrm{N}_{2}$ (normoxia); as described in detail in Pane \& Barry (2007). Cancer magister (at $10^{\circ} \mathrm{C}$ ) and Chionoecetes tanneri (at $3.5^{\circ} \mathrm{C}$ ) held in the laboratory under normoxia were exposed to seawater equilibrated with the cylinder containing $20 \% \mathrm{O}_{2}$, while $C$. tanneri (again at $3.5^{\circ} \mathrm{C}$ ) held in the laboratory under hypoxia was exposed to seawater equilibrated with the cylinder containing $3 \% \mathrm{O}_{2}$. During hypercapnic exposure, individuals of each species were held in individual (12 or 20 l) darkened and sealed chambers with no head space and served by a water flow of $50 \mathrm{ml} \mathrm{min}{ }^{-1}$. Oxygen concentrations in these 2 treatments were 95 and $14 \%$, respectively. It is following these $24 \mathrm{~h}$ exposures that tissues were sampled for measurements of ATPase activity and buffering capacity. 
All prehypercapnic data were collected by sampling a subset of individuals prior to the appropriate $\mathrm{CO}_{2}$ exposure.

For all sampling, crabs were anaesthetized for $3 \mathrm{~min}$ in a slurry of ice and seawater, then sacrificed by immediate removal of the dorsal carapace. The heart and the eighth (posterior) gill on the right side were excised immediately, snap-frozen in liquid nitrogen, and stored at $-80^{\circ} \mathrm{C}$ for future analyses. Simultaneously, the most anterior walking leg on the left side was removed and snap-frozen in liquid nitrogen. The leg was then removed from the liquid nitrogen, and, while frozen, the exoskeleton was split and the white muscle was removed, snap-frozen, and stored at $-80^{\circ} \mathrm{C}$.

Tissue buffering capacity. In vitro buffering capacities $(\beta)$ of crab heart and muscle were determined by basic titration according to the method of Castellini \& Somero (1981). Heart ( 50 to $150 \mathrm{mg}$ ) and white muscle ( 200 to $500 \mathrm{mg})$ tissues were weighed to the nearest milligram, thawed in $10 \mathrm{ml}$ of $0.9 \% \mathrm{NaCl}$, and homogenized with a Brinkman PT 10/35 tissue homogenizer. Homogenates were equilibrated to room temperature $\left(19^{\circ} \mathrm{C}\right)$, and the $\mathrm{pH}$ of the homogenate was measured (IQ 240; Scientific Instruments). As necessary, $0.02 \mathrm{~N} \mathrm{HCl}$ was added to bring the starting $\mathrm{pH}$ to 6. Homogenates were then titrated, with constant stirring, to a pH of 7 with $0.2 \mathrm{~N}$ (muscle) or $0.05 \mathrm{~N}$ (heart) $\mathrm{NaOH}$ solutions calibrated to a temperature-appropriate $\mathrm{pH}$ of normality ( $\mathrm{pN}$ ) against a standardized solution of $\mathrm{HCl}$ (Fisher Scientific). Buffering capacities were then expressed as Slykes, or $\mu$ moles of base needed to effect a 1 unit of pH change (6 to 7) in $1 \mathrm{~g}$ of wet tissue.

ATPase activities. ATPase activities of white muscle, heart and gill tissues were measured using a coupled pyruvate kinase/lactate dehydrogenase assay following changes in $\mathrm{NADH}$ absorption at $340 \mathrm{~nm}$, as described in McCormick (1993), with modifications according to Goffredi \& Childress (2001). Tissue aliquots (50 to $150 \mathrm{mg}$ ) were thawed in $\sim 5 \mathrm{vol}$ of icecold buffer composed of sucrose (250 mM), $\mathrm{Na}_{2}$ EDTA (10 mM), imidazole (50 mM), and sodium deoxycholate $\left(1 \mathrm{mg} \mathrm{ml}^{-1}\right), \mathrm{pH}=7.40$, then gently homogenized on ice in a glass douncer. Homogenates were centrifuged at $5000 \times g$ for $30 \mathrm{~s}$ at $4^{\circ} \mathrm{C}$, and supernatants were incubated at room temperature with various inhibitors (Table 1). The assay was then started by the addition of supernatant/inhibitor solutions to the ATPase activity solution containing imidazole (50 mM), phosphoenolpyruvate (PEP; $2.1 \mathrm{mM})$, reduced nicotinamide adenine dinucleotide $\left(\mathrm{NADH}_{;} 0.17 \mathrm{mM}\right)$, adenosine triphosphate (ATP; $0.53 \mathrm{mM})$, lactate dehydrogenase $\left(\mathrm{LDH}_{;} \mathrm{EC} 1.1 .1 .27 ; 3.5 \mathrm{U} \mathrm{ml}^{-1}\right)$, pyruvate kinase $\left(\mathrm{PK}_{\mathrm{i}}\right.$ EC 2.7.1.40; $3.8 \mathrm{U} \mathrm{ml}^{-1}$ ), $\mathrm{NaCl}$ (47.25 mM), $\mathrm{MgCl}_{2}$ (2.6 mM), and $\mathrm{KCl}(21 \mathrm{mM}), \mathrm{pH}$ 7.4. Oxidation of NADH was followed spectrophotometrically (Spectramax 340 PC; Molecular Devices) for $10 \mathrm{~min}$ at $25^{\circ} \mathrm{C}$, against standardized solutions of adenosine diphosphate (ADP). ATPase activity was normalized to protein concentration, as measured using Coomassie Blue and albumin protein standards (Bradford 1976).

Total ATPase activity was measured in each supernatant after incubation with double-distilled water. The ATPase activities of specific fractions were then derived by the subtraction of inhibited ATPase rates from total ATPase activity. Inhibition of activity was calculated as a decrease in activity beyond that caused by the solvent.

Inhibitor concentrations and incubation times were minimized (Table 1), while still achieving maximal inhibition using dose- and time-dependent curves (data not shown).

Carbonic anhydrase activity. Tissue carbonic anhydrase (CA) activity was measured as described by Henry et al. (1990), with the exceptions that homogenization was by hand in a glass douncer and homogenates (rather than supernatants) were assayed. Data acquisition $(\Delta \mathrm{pH})$ followed the methods of Blanchard \& Grosell (2006).

Whole animal oxygen uptake. Temperature-dependent rates of oxygen consumption $\left(\mathrm{MO}_{2}\right)$ were determined via closed-cell respirometry on both crab species acclimated to normoxia. Crabs were placed individually in darkened 201 chambers and allowed to settle for 4 to $8 \mathrm{~h}$ under flowing seawater of the appropriate temperature $\left(3.8^{\circ} \mathrm{C}\right.$ for Chionoecetes tanneri and $9.5^{\circ} \mathrm{C}$ for Cancer magister). Gentle recirculation within the chamber was driven by a submersible pump. Flow was then stopped, the chambers sealed, and oxygen drawdown was measured over a 40 to 120 min period using an Aanderaa immersion oxygen optrode (Aanderaa 
Data Instruments) coupled to a PC running LabVIEW software (National Instruments). Appropriate oxygen solubility constants from Boutilier et al. (1984) and wet weights were used to calibrate mass-specific $\mathrm{MO}_{2}$. Rates of oxygen consumption were corrected for 'blank' oxygen consumption by the experimental apparatus $(\sim 0.1 \%$ of whole animal rates) in the absence of crabs. $\mathrm{MO}_{2}$ was measured in both species in normocapnic seawater with $\sim 50$ to $80 \%$ oxygen saturation.

Statistical analyses. All measured values are presented as means \pm 1 standard error of the mean (SEM; $\mathrm{n}=$ number of crabs). The Shapiro-Wilks test for normality and the Levene test for homogeneity of variance were conducted on raw data prior to statistical treatment. Data meeting these assumptions were analyzed for significant differences using a 1-way ANOVA followed by a Bonferroni's post hoc multiple comparison test. Data not meeting parametric assumptions were compared with a Kruskal-Wallis test followed by multiple comparison testing according to the method of Dunn (1964), as described by Zar (1984). The $\mathrm{p}<0.05$ level was used for statistical significance in all cases. Oxygen consumption rates in the 2 species and CA activities in various tissues were compared by an unpaired 2-tailed Student's $t$-test.

\section{RESULTS}

\section{ATPase activities}

Prior to hypercapnic exposure, all forms of ATPase activity in the posterior gills of the crab species studied (including total ATPase, $\mathrm{Na}^{+}-\mathrm{K}^{+}$-ATPase, and amiloride-sensitive ATPase) were significantly higher in Cancer magister than in Chionoecetes tanneri acclimated to either oxygen regime (Fig. 1). ATPase activities in C. tanneri posterior gills were 2- to 5 -fold lower than in C. magister gills.

In the posterior gill of Cancer magister, $24 \mathrm{~h}$ of highlevel hypercapnia had an inhibitory effect on all forms of ATPase activity (Fig. 1). Conversely, ATPase activities in Chionoecetes tanneri gills were unaffected by hypercapnia (Fig. 1).

Muscle ATPase activity followed a different pattern, with similar pre- and post-hypercapnic levels of total ATPase activity across the 3 treatments (Fig. 2). Prehypercapnia, however, both amiloride- and NEMsensitive ATPase activities were significantly lower in white muscle from Chionoecetes tanneri acclimated to normoxia (Fig. 2).

Measurements of total and amiloride-sensitive ATPase activity for crab heart tissues showed no difference across the 3 treatments either prior to or following short-term hypercapnic exposure (Fig. 3).

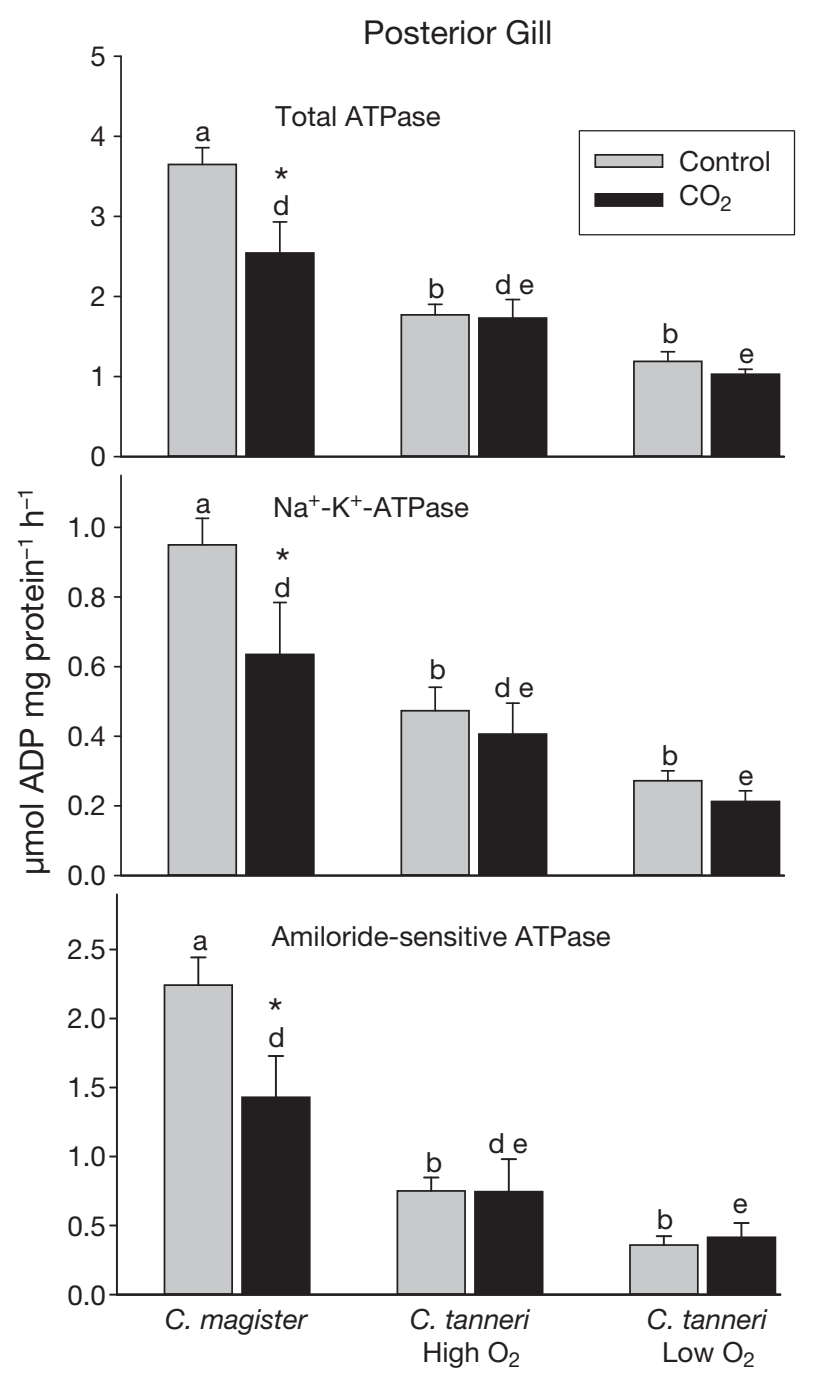

Fig. 1. Cancer magister and Chionoecetes tanneri. ATPase activities in the posterior gills of C. magister and of C. tanneri held under 2 different oxygen regimes, both before and after short-term (24 h), high-level (1\%) hypercapnic exposure. Bars not sharing the same letter within the same treatment (pre- or post-hypercapnia) are significantly different. Asterisk denotes a significant difference between pre- and post-hypercapnic responses. Data are means \pm 1 SEM ( $n=4$ to 6 ): total

ATPase, $\mathrm{Na}^{+}-\mathrm{K}^{+}$-ATPase and amiloride-sensitive ATPase

\section{Tissue buffering capacities}

Prior to hypercapnic exposure, in vitro non-bicarbonate buffering capacity of crab muscle tissue $(\beta)$ mimicked the pattern for NEM- and amiloride-sensitive muscle ATPase activity (Fig. 4; cf. Fig. 2). The buffering capacity of pre-hypercapnic white muscle was significantly lower ( $30 \%$ reduction) in normoxic Chionoecetes tanneri than of muscle tissue from Cancer magister. However, $24 \mathrm{~h}$ of short-term hypercapnia negated this difference, resulting in similar post-hypercapnic $\beta$-levels among the 3 treatments. 


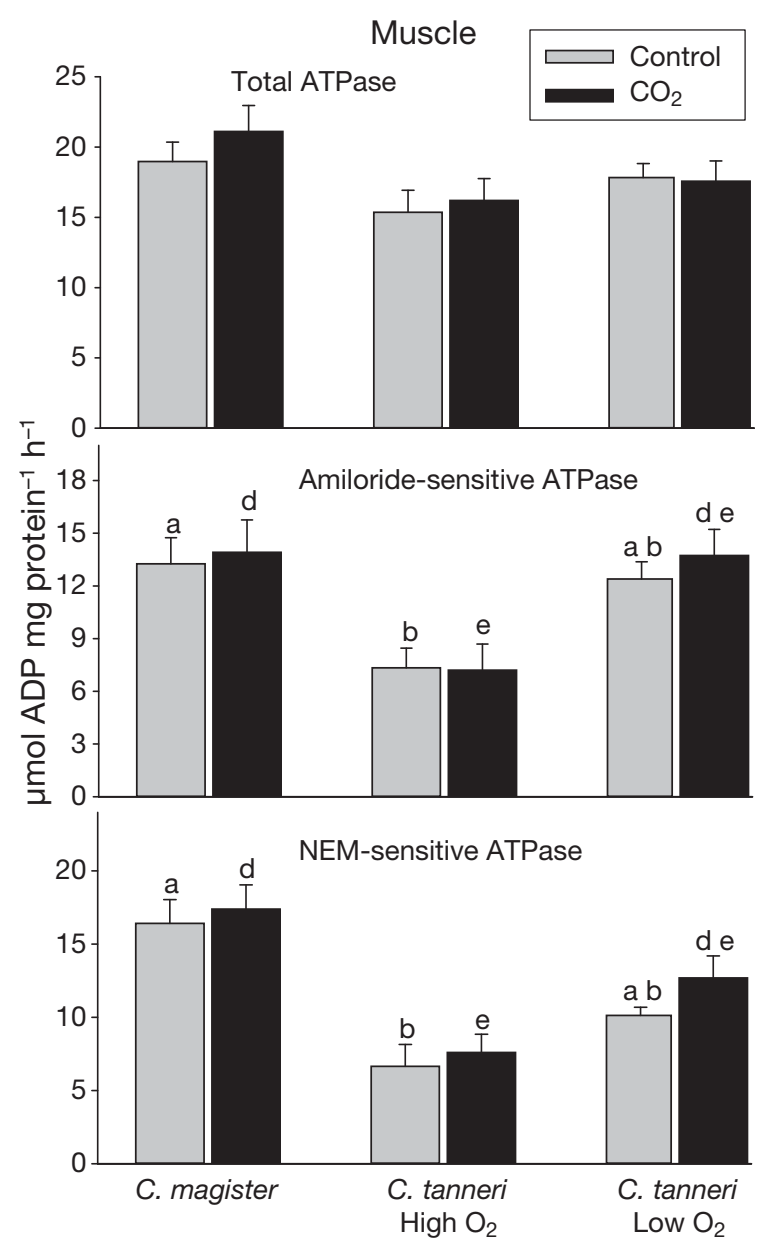

Fig. 2. Cancer magister and Chionoecetes tanneri. ATPase activities in white muscle of $C$. magister, and of $C$. tanneri held under 2 different oxygen regimes, both before and after short-term (24 h), high-level (1 \%) hypercapnic exposure. Bars not sharing the same letter within the same treatment (pre- or post-hypercapnia) are significantly different. Data are means \pm 1 SEM $(\mathrm{n}=4$ to 6$)$ : total ATPase, amiloride-sensitive ATPase and N-ethylemaleimide (NEM)-sensitive ATPase

The buffering capacity of crab heart tissue did not vary significantly among the 3 treatments prior to or following acute exposure to elevated levels of $\mathrm{CO}_{2}$ (Fig. 4).

\section{Carbonic anhydrase activities}

Normocapnic levels of tissue CA activity were compared between Cancer magister held in normoxic seawater and Chionoecetes tanneri kept in low oxygen (10\% saturation), mimicking typical in situ conditions. In white muscle and heart tissues, C. magister CA activity was approximately 3 times higher than that measured for $C$. tanneri, with the difference approaching a 14 -fold increase in posterior gills (Fig. 5).

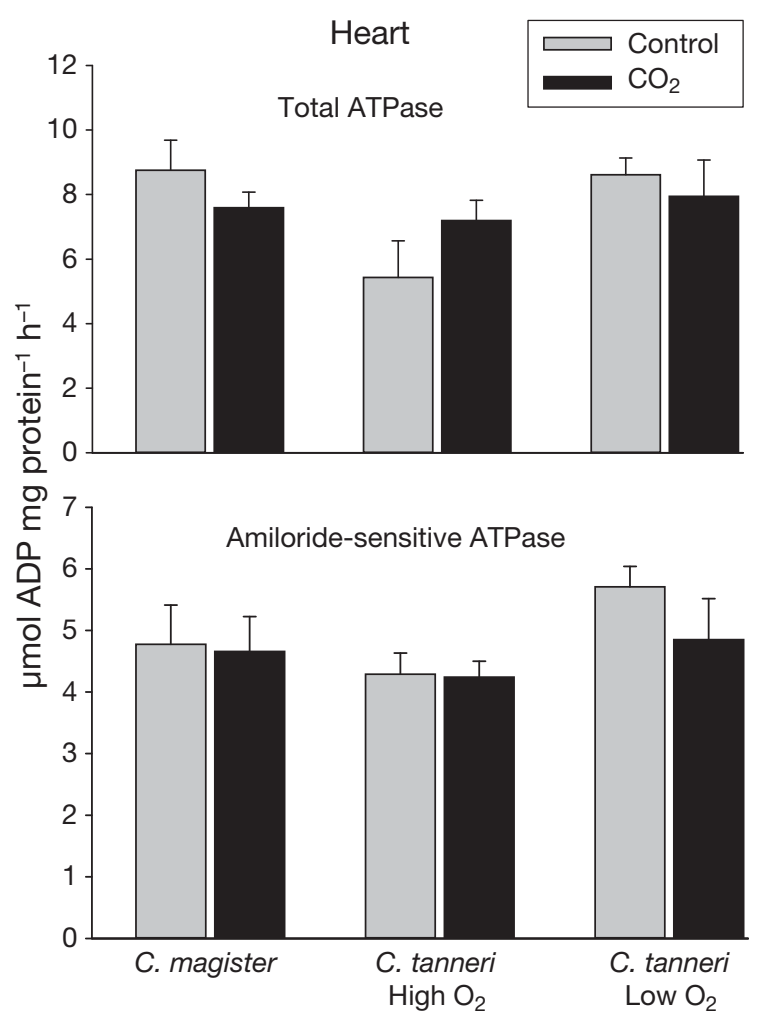

Fig. 3. Cancer magister and Chionoecetes tanneri. ATPase activities in hearts of $C$. magister and of $C$. tanneri held under 2 different oxygen regimes, both before and after short-term (24 h), high-level (1\%) hypercapnic exposure. Data are means \pm 1 SEM ( $\mathrm{n}=4$ to 6 ): total ATPase and amiloride-sensitive ATPase

\section{Whole animal oxygen uptake}

Chionoecetes tanneri acclimated to normoxia exhibited mass-specific rates of oxygen consumption $\left(\mathrm{MO}_{2}\right)$ significantly lower (4.5-fold) than did Cancer magister similarly acclimated. $\mathrm{MO}_{2}$ in $C$. tanneri was $0.51 \pm$ $0.09 \mu \mathrm{mol} \mathrm{O} \mathrm{g}^{-1} \mathrm{~h}^{-1}(\mathrm{n}=8)$ versus $2.31 \pm 0.51 \mu \mathrm{mol}$ $\mathrm{O}_{2} \mathrm{~g}^{-1} \mathrm{~h}^{-1}(\mathrm{n}=6)$ in C. magister.

\section{DISCUSSION}

Oxygen uptake experiments using whole animals confirmed the hypometabolism of the deep-sea Tanner crab Chionoecetes tanneri when compared to the nearshore Dungeness crab Cancer magister. Though a temperature difference of about 5.5 to $6.0^{\circ} \mathrm{C}$ was a necessary respirometric variable due to thermal tolerances, particularly in Tanner crabs, direct temperature corrections of the respirometric data to a median temperature of $6.7^{\circ} \mathrm{C}$, using either a $Q_{10}$ of 2.0 or the method of Gillooly et al. (2001), yield either a 3.0- or 2.8-fold difference, respectively, in $\mathrm{MO}_{2}$ between the 2 species. 


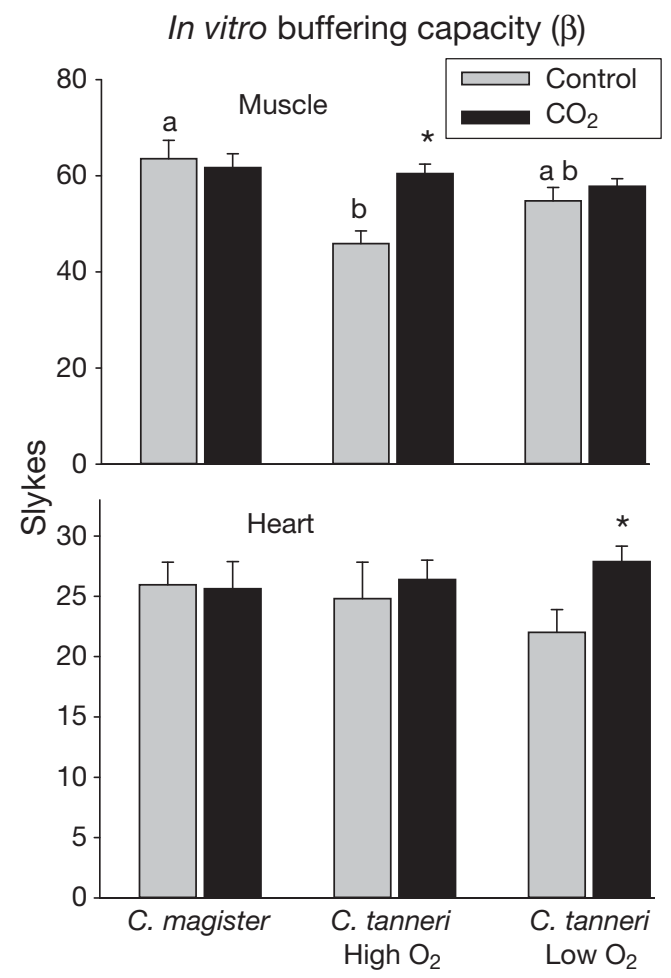

Fig. 4. Cancer magister and Chionoecetes tanneri. In vitro non-bicarbonate buffering capacity $(\beta)$ of tissues from $C$. magister, and from $C$. tanneri held under 2 different oxygen regimes, both before and after short-term $(24 \mathrm{~h})$, high-level (1\%) hypercapnic exposure. Bars not sharing the same letter within the same treatment (pre- or post-hypercapnia) are significantly different. Asterisk denotes a significant difference between pre- and post-hypercapnic responses. Data are means \pm 1 SEM ( $n=5$ to 6$)$ : white muscle and heart

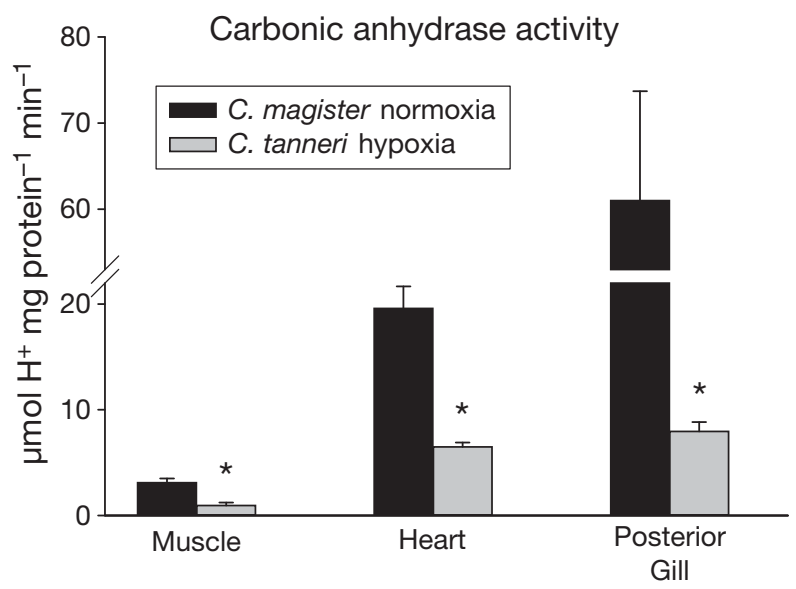

Fig. 5. Cancer magister and Chionoecetes tanneri. Carbonic anhydrase (CA) activity in tissues from C. magister, and from $C$. tanneri held under 2 different oxygen regimes. Asterisk denotes a tissue-specific significant difference in CA rates between species. Data are means \pm 1 SEM ( $n=6$ to 7 ). Note the break in the $y$-axis
Our respirometric data coincide closely with previously published values. In the genus Chionoecetes, Paul \& Fuji (1989) measured an oxygen consumption rate of $\sim 0.6 \mu \mathrm{mol} \mathrm{O}_{2} \mathrm{~g}^{-1} \mathrm{~h}^{-1}$ in $C$. bairdi at a similar temperature $\left(4\right.$ to $\left.5^{\circ} \mathrm{C}\right)$. For the Dungeness crab, our experimental rate of $2.3 \mu \mathrm{mol} \mathrm{O} \mathrm{O}^{-1} \mathrm{~h}^{-1}$ falls between 2 other Dungeness respiration rates of 1.4 (Johansen et al. 1970) and $3.0 \mu \mathrm{mol} \mathrm{O} \mathrm{O}^{-1} \mathrm{~h}^{-1}$ (McDonald et al. 1980), with all 3 values recorded at $10^{\circ} \mathrm{C}$.

In sighted pelagic animals, the visual/predator hypothesis states that limited light with depth reduces visual predation pressure and selects for reduced locomotory abilities and metabolic capacities at depth (Seibel et al. 1997, Childress \& Seibel 1998). Predominantly applicable to pelagic animals, the suitability of this theory to sluggish and hypoactive deep-sea benthic fauna such as Chionoecetes tanneri is less clear. While Tanner crabs have a much lower respiration rate than Dungeness crabs, even after temperature correction-data that coincide with other observations of deep-sea benthic animal metabolic rates up to an order of magnitude less than those of more near-shore counterparts (Henry et al. 1990) - the comparison in the present study is somewhat limited by phylogenetic constraints.

Rather than speculating on the putative evolutionary origins of the different metabolic rates that we observed in the 2 species, we focus here on the ecological practicality of the differences observed in $\mathrm{MO}_{2}$. Hypometabolism in Chionoecetes tanneri will greatly constrain its ability to actively regulate internal acid-base status during hypercapnic exposure, a process requiring substantial metabolic energy. Many of the prehypercapnic differences described below, wherein Tanner crabs consistently displayed reduced enzymatic activities, may be directly attributable to hypometabolism.

When we compared the 2 most physiologically relevant treatments, normoxic Dungeness crabs versus hypoxic Tanner crabs, the deep-sea Tanner crab exhibited lower activities of branchial enzymes involved in some of the processes essential for efficient acidbase regulation. Prior to hypercapnic exposure (i.e. under normocapnic conditions), activities of all forms of ATPase and CA in the posterior gill were approximately 2- to 13.2-fold lower in Tanner crabs than in Dungeness crabs (Figs. 1 \& 5). A similar scope of 1.5- to 20 -fold lower activity was found in an assortment of metabolic enzymes from the deep-sea crabs Chaceon fenneri and Chaceon quinquedens, when compared to the sublittoral Callinectes sapidus (Walsh \& Henry 1990).

In decapod crabs, the gill is the primary site for key acid-base and ionoregulatory ion transport processes (Cameron 1986, Henry \& Wheatly 1992, Pequeux 1995). 
In particular, the posterior gills (Gills 5 to 8) bear the brunt of this work. Unlike marine fishes (Marshall \& Grosell 2005), crabs do not supplement acid-base relevant branchial ion transport with gastrointestinal tract or renal ion transport to any substantial degree (Pequeux 1995). Reductions in ATP-dependent and acid-base relevant enzymatic activity in the Tanner crab gill, then, are likely to cause substantial limitations in acid-base regulatory capacity.

The mechanisms of branchial transmembrane and transepithelial transport of acid-base relevant ions are highly conserved across animal phyla and represent one of the most important, but metabolically costly, means of defending intracellular $\mathrm{pH}$ (Seibel \& Walsh 2001, 2003). One example of transepithelial branchial ion transport is proton exchange between extracellular fluid and seawater, whereby protons are excreted from the gill to combat internal acidosis. Protons are supplied by $\mathrm{CA}$, which hydrates $\mathrm{CO}_{2}$ to form carbonic acid, which then dissociates to $\mathrm{H}^{+}$and $\mathrm{HCO}_{3}^{-}$ions available for transport. Very low CA activity in the posterior gills (and other tissues) of the deep-sea Tanner crab (Fig. 5) coincides with physiological data demonstrating uncompensated extracellular acidosis in this species exposed to short-term, high-level hypercapnia (Pane \& Barry 2007).

Another important component to branchial proton excretion is sodium-proton antiport, accomplished by the sodium proton exchanger NHE. Like many transport processes, sodium-proton exchange relies on $\mathrm{Na}^{+}$ gradients established in large by $\mathrm{Na}^{+}-\mathrm{K}^{+}$-ATPase. Both the more traditional cardiac glycoside-sensitive fraction of $\mathrm{Na}^{+}-\mathrm{K}^{+}$-ATPase activity assayed using the inhibitors ouabain and ouabagenin (Goffredi \& Childress 2001; Fig. 1) and an amiloride-sensitive fraction (Soltoff \& Mandel 1983, Ellis-Davies et al. 1996; Fig. 1) were markedly lower in hypoxic Tanner crabs than in normoxic Dungeness crabs, further suggesting inefficient acid-base (and ionoregulatory) transport processes.

In the low micromolar range, amiloride is a potent inhibitor of sodium-proton exchange. In the low millimolar range, however, amiloride targets $\mathrm{Na}^{+}-\mathrm{K}^{+}$-ATPase, directly inhibiting its activity (Soltoff \& Mandel 1983). At an amiloride concentration of $2.5 \mathrm{mM}$, we observed a 20 to $60 \%$ inhibition of $\mathrm{Na}^{+}-\mathrm{K}^{+}$-ATPase activity across species, tissues, and treatments. Using $2 \mathrm{mM}$ amiloride, Soltoff \& Mandel (1983) observed a 30 to $45 \%$ inhibition of $\mathrm{Na}^{+}-\mathrm{K}^{+}$-ATPase activity in isolated rabbit kidney proximal tubules. We have therefore used amiloride as an additional pharmacological tool to demonstrate reduced ATP-dependent enzymatic activity in gill and muscle tissue of deep-sea Tanner crabs.

It is important to note, however, that amiloride is a highly non-specific inhibitor of $\mathrm{Na}^{+}-\mathrm{K}^{+}$-ATPase. There is some evidence that an amiloride-sensitive fraction of $\mathrm{Na}^{+}-\mathrm{K}^{+}$-ATPase activity may overlap with the more traditional cardiac glycoside (ouabain or ouabagenin)sensitive ATPase activity (Epstein \& Lechene 1988), but the mechanisms of amiloride inhibition are, to date, poorly characterized. This leaves the possibility that amiloride, applied to locomotory or contractile tissue such as white muscle and heart, respectively, may inhibit a substantial portion of ATPase activity related to these muscular activities, but may not be particularly associated with transmembrane transport of acidbase relevant ions. However, when applied to white muscle, amiloride and the highly specific P-type inhibitor NEM show very similar patterns of inhibition (Fig. 2), suggesting that these 2 inhibitors may target similar (P-type) fractions of ATPase activity.

A second diagnostic comparison was made between the 2 species of crab, both held in normoxia. In this comparison, significant pre-hypercapnic differences appeared between the species in white muscle enzymatic activities (Fig. 2) and non-bicarbonate tissue buffering ( $\beta$ ) capacity (Fig. 4). In addition to the white muscle amiloride-sensitive ATPase fraction described above, the more broad P-type ATPase activity, strongly sensitive to NEM inhibition (Lin \& Randall 1993, Gerencser \& Zhang 2001, Goffredi \& Childress 2001), was significantly lower in normoxic Tanner crab white muscle (Fig. 2). $\mathrm{Na}^{+}-\mathrm{K}^{+}$-ATPase activity, being an abundant P-type (membrane bound) ATPase, likely comprises a large fraction of the NEM-sensitive activity observed, though there are several other P-type ATPases with certain acid-base and iono-regulatory importance. These include $\mathrm{H}^{+}$-ATPase, shown to be NEM sensitive (Lin \& Randall 1993) and critical to proton export for intracellular $\mathrm{pH}$ regulation, as well as P-type $\mathrm{Cl}^{-}$-ATPase (Gerencser \& Zhang 2001), which is also NEM sensitive and critical to anion (and indirectly $\mathrm{HCO}_{3}{ }^{-}$) balance. P-type metal ATPases such as Zn-, $\mathrm{Cu}$-, or Co-ATPase also have key ionoregulatory functions, and may be secondarily important in acid-base balance.

It is of interest that significantly reduced amilorideand NEM-sensitive ATPase activity in Tanner crab muscle occurred only in the normoxic comparison. Similar results were found for Tanner crab muscle buffering capacity, suggesting that exposure to relatively high levels of oxygen effected these changes. We speculate that the reduced $\beta$ levels in Tanner crab muscle are a direct function of normoxia. Tanner crabs acclimated to typical hypoxic in situ conditions of the oxygen minimum zone would be exposed to anomalously high oxygen levels when exposed to normoxic seawater, resulting in a highly aerobic physiological state. Passive buffering is one of the more straightforward means of defending intracellular $\mathrm{pH}$ (Seibel 
\& Walsh 2001), and resting $\beta$ levels in muscle are inversely correlated to the extent to which a tissue experiences anaerobisis (Castellini \& Somero 1981, Henry \& Wheatly 1992, Wheatly \& Henry 1992). Therefore, our Tanner crabs held at relatively high oxygen values (normoxia) and presumably not under the threat of anaerobisis, exhibited a lower resting muscle $\beta$ than the more metabolically active Dungeness crabs held under normoxia, or Tanner crabs held in hypoxic seawater.

The observed reductions in amiloride- and NEMspecific muscle ATPase under prehypercapnic conditions (Fig. 2) may also be a function of normoxic conditions in the laboratory. However, the connection between oxygen levels and depressed rates of muscle ATPase activity is less clear and a subject for further study, including a detailed analysis of ion gradients in the muscle of Tanner crabs held under different oxygen regimes.

A notable physiological effect of short-term hypercapnia was a 30 to $40 \%$ reduction in all forms of posterior gill ATPase activity in Dungeness crabs (Fig. 1). A number of studies have shown that $\mathrm{CO}_{2}$ can cause metabolic suppression in invertebrates (Barnhart \& McMahon 1988, Barnhart 1989, Rees \& Hand 1990, Michaelidis et al. 2005), though substantial reductions in extracellular (blood or hemolymph) $\mathrm{pH}$ appear to drive this reduction (Michaelidis et al. 2005). Within $24 \mathrm{~h}$, Dungeness crabs exposed to high-level $\mathrm{CO}_{2}(1 \%)$ completely restored extracellular $\mathrm{pH}$ to normocapnic values (Pane \& Barry 2007), indicating that $\mathrm{CO}_{2}$ may have a more direct inhibitory effect on branchial ATPase activity in this species. Alternatively, branchial ATPase activity in the sublittoral Dungeness crab may be indirectly inhibited by the marked shift in proton (and other ion) gradients across the gill caused by hypercapnic exposure.

No reduction in ATPase activity following short-term (24 h) hypercapnia was observed in any Tanner crab tissue. This may be a direct function of hypometabolism in this species, where such a minimal aerobic scope for activity limits the ability to tune metabolic rate to changing environmental conditions.

In a previous study (Pane \& Barry 2007), both hypoxic- and normoxic-adapted Tanner crabs experienced an uncompensated 0.4 unit drop in extracellular $\mathrm{pH}$ during the same $\mathrm{CO}_{2}$ exposure regime. In light of these previous findings, the increase in passive buffering capacity ( $\beta$ ) of muscle from Tanner crabs acclimated only to normoxia (Fig. 4) may indicate an effort in this treatment to defend intracellular $\mathrm{pH}$ after $24 \mathrm{~h}$ of hypercapnia. In Tanner crabs acclimated to hypoxia, pre-hypercapnic $\beta$-levels were higher and subsequently unchanged by hypercapnia (Fig. 4), suggesting that hypoxia pre-conditioned the buffering capacity of Tanner crab muscle. Such an effect is consistent with the relationship described above, wherein the hypoxic Tanner crab, presumably better conditioned to anaerobic events, maintains a higher muscle buffering capacity and is therefore better suited to defend intracellular $\mathrm{pH}$ by passive means during extracellular acidosis (Seibel \& Walsh 2001, 2003).

\section{CONCLUSIONS}

The specific effects of hypercapnia on crab tissue were less revealing than the marked pre-hypercapnic, interspecific differences between the deep-sea Tanner crab and the Dungeness crab. We have previously reported (Pane \& Barry 2007) that extracellular acidbase regulatory strategies between the 2 species during short-term hypercapnia are a study in contrast. The Dungeness crab perfectly compensated extracellular $\mathrm{pH}$ during hypercapnia, while the Tanner crab left extracellular $\mathrm{pH}$ undefended. Presumably, Tanner crabs use their limited metabolic energy to defend the more critical intracellular $\mathrm{pH}$, as is the case in other sluggish aquatic animals (Brauner et al. 2004); this is an area we are currently investigating.

Even with adequate intracellular $\mathrm{pH}$ regulation, the current data provide a very strong explanation for inefficient regulation of hemolymph $\mathrm{pH}$ in Tanner crabs. The reduced scope of enzymatic (particularly branchial) activities in Tanner crabs, consistent with hypometabolism, render these animals incapable of efficient transport of ionic and acid-base equivalents to combat short-term hypercapnia. Under a carbon sequestration scenario to offset rising atmospheric $\mathrm{CO}_{2}$ levels, this is exactly the situation that deep-sea benthic fauna may face. This scenario calls for the injection of large amounts of liquid $\mathrm{CO}_{2}$ into the deep sea, either on the bottom or as a $\mathrm{CO}_{2}$-rich middepth plume (Adams et al. 1998). Either scenario or the mixing of anthropogenic carbon from surface waters to the deep sea will result in significant reductions in ocean $\mathrm{pH}$, particularly near $\mathrm{CO}_{2}$ injection sites.

While our results indicate that Tanner crabs will be unable to defend extracellular $\mathrm{pH}$ during acute hypercapnia, the story is less clear for putative chronic (permanent) hypercapnia. If chronic hypercapnia proves to be equally disturbing to the extracellular acid-base status of this deep-water species, the pursuant costs of such a compromise are likely to include impaired oxygen transport, tissue oxygenation and overall metabolic capacity, reduced growth and reproductive capacity, and possible implications for prey capture and predator avoidance. 
Acknowledgements. We are grateful for the work of the crews of the RV 'Point Lobos' and the ROV 'Ventana'. Additionally, we thank Patrick Whaling, Kurt Buck, Chris Lovera, and Jon Blanchard for their assistance. These studies were supported by the Monterey Bay Aquarium Research Institute (Project 200002), the Ocean Carbon Sequestration Research Program, Biological and Environmental Research (BER), U.S. Department of Energy (Award Nos. DE-FG03-01DF63065 \& DEFG02-04ER63721), and the National Energy Technology Laboratory (NETL), U.S. Department of Energy (Award No. DE-FC26-00NT40929).

\section{LITERATURE CITED}

Adams EE, Caulfield AJ, Herzog HJ, Auerbach DI (1998) Impacts of reduced $\mathrm{pH}$ from ocean $\mathrm{CO}_{2}$ disposal: sensitivity of zooplankton mortality to model parameters. Waste Manag 17:375-380

Ahearn GA, Duerr JM, Zhuang Z, Brown RJ, Aslamkhan A, Killebrew DA (1999) Ion transport processes of crustacean epithelial cells. Physiol Biochem Zool 72:1-18

Barnhart MC, McMahon BR (1988) Depression of aerobic metabolism and intracellular $\mathrm{pH}$ by hypercapnia in land snails, Otala lacteal. J Exp Biol 138:289-299

Barnhart MC (1989) Respiratory acidosis and metabolic depression in dormant invertebrates. In: Malan A, Canguilhem B (eds) Living in the cold. Colloque INSERM/ John Libbey Eurotext, London, p 315-401

Blanchard J, Grosell M (2006) Copper toxicity across salinities from freshwater to seawater in the euryhaline fish Fundulus heteroclitus: Is copper an ionoregulatory toxicant in high salinities? Aquat Toxicol 80:131-139

Boutilier RG, Heming TA, Iwama GK (1984) Physiochemical parameters for use in fish respiratory physiology. In: Hoar WS, Randall DJ (eds) Fish physiology. Academic Press, London, p 403-430

Bradford MM (1976) A rapid and sensitive method for the quantitation of microgram quantities of protein utilizing the principle of protein-dye binding. Anal Biochem 72: 248-254

Brauner CJ, Wang T, Wang Y, Richards JG and others (2004) Limited extracellular but complete intracellular acid-base regulation during short-term environmental hypercapnia in the armoured catfish, Liposarcus pardalis. J Exp Biol 207:3381-3390

Cameron JN (1986) Acid-base equilibria in invertebrates. In: Heisler N (ed) Acid-base regulation in animals. Elsevier, New York, p 357-394

Castellini MA, Somero GN (1981) Buffering capacity of vertebrate muscle: correlations with potentials for anaerobic function. J Comp Physiol 143:191-198

> Childress JJ (1995) Are there physiological and biochemical adaptations of metabolism in deep-sea animals? Trends Ecol Evol 10:30-36

Childress JJ, Seibel BA (1998) Life at stable low oxygen levels: adaptations of animals to oceanic oxygen minimum layers. J Exp Biol 201:1223-1232

Company JB, Thuesen EV, Childress JJ, Rotllant G, Zal F (2008) Effects of food deprivation on enzymatic activities of the Mediterranean deep-sea crab, Geryon longipes A. Milne-Edwards, 1882 and the Pacific hydrothermal vent crab, Bythograea thermydron Williams, 1980 (Decapoda, Brachyura). Crustaceana 81:67-85

> Dunn OJ (1964) Multiple contrasts using rank sums. Technometrics 6:241-252

Ellis-Davies GCR, Kleyman TR, Kaplan JH (1996) Photo- labile amiloride derivatives as cation site probes of the Na,K-ATPase. J Biol Chem 271:10353-10358

Epstein JA, Lechene C (1988) Ouabain-resistant amiloridesensitive $\mathrm{Na}^{+}-\mathrm{K}^{+}$pumping activity and morphological changes are inducible. Am J Physiol 254:C847-C854

Feely RA, Sabine CL, Lee K, Berelson W, Kleypas J, Fabry VJ, Millero FJ (2004) Impact of anthropogenic $\mathrm{CO}_{2}$ on the $\mathrm{CaCO}_{3}$ system in the oceans. Science 305:362-366

Gage JD, Tyler PA (1991) Deep-sea biology - a natural history of organisms at the deep-sea floor. Cambridge University Press, Cambridge

Gerencser GA, Zhang J (2001) The Aplysia californica $\mathrm{Cl}^{-}$ pump is a P-type ATPase: evidence through inhibition studies. Can J Physiol Pharmacol 79:472-475

Gillooly JF, Brown JH, West GB, Savage VM, Charnov EL (2001) Effects of size and temperature on metabolic rate. Science 293:2248-2251

Goffredi SK, Childress JJ (2001) Activity and inhibitor sensitivity of ATPases in the hydrothermal vent tubeworm Riftia pachyptila: a comparative approach. Mar Biol 138:259-265

Henry RP, Cameron JN (1983) The role of carbonic anhydrase in respiration, ion regulation and acid-base balance in the aquatic crab Callinectes sapidus and the terrestrial crab Gecarcinus lateralis. J Exp Biol 103:205-223

Henry RP, Wheatly MG (1992) Interaction of respiration, ion regulation, and acid-base balance in the everyday life of aquatic crustaceans. Am Zool 32:407-416

Henry RP, Perry HM, Trigg CB, Handley HL, Krarup A (1990) Physiology of two species of deep-water crabs, Chaceon fenneri and C. quinquedens: gill morphology and hemolymph ionic and nitrogen concentrations. J Crustac Biol 10:375-381

> Johansen K, Lenfant C, Mecklenburg TA (1970) Respiration in the crab, Cancer magister. Z Vgl Physiol 70:1-19

Kennett JP, Ingram BL (1995) A 20,000-year record of ocean circulation and climate change from the Santa Barbara basin. Nature 377:510-514

Lin H, Randall DJ (1993) $\mathrm{H}^{+}$-ATPase activity in crude homogenates of fish gill tissue: inhibitor sensitivity and environmental and hormonal regulation. J Exp Biol 180:163-174

> Marchetti C (1977) On geoengineering and the $\mathrm{CO}_{2}$ problem. Clim Change 1:59-68

Marchetti C (1979) Constructive solutions to the $\mathrm{CO}_{2}$ problem. In: Bach W, Pankrath J, Kellogg W (eds) Man's impact on climate. Elsevier Science, Amsterdam, p 299-311

Marshall WS, Grosell M (2005) Ion transport, osmoregulation and acid-base balance. In: Evans D (ed) The physiology of fishes. CRC Press, London, p 177-231

McCormick SD (1993) Methods for nonlethal gill biopsy and measurement of $\mathrm{Na}^{+}, \mathrm{K}^{+}$-ATPase activity. Can J Fish Aquat Sci 50:656-658

> McDonald DG, Wood CM, McMahon BR (1980) Ventilation and oxygen consumption in the Dungeness crab, Cancer magister. J Exp Zool 213:123-136

> Michaelidis B, Ouzounis C, Paleras A, Pörtner HO (2005) Effects of long-term moderate hypercapnia on acid-base balance and growth rate in marine mussels Mytilus galloprovincialis. Mar Ecol Prog Ser 293:109-118

Pane EF, Barry JP (2007) Extracellular acid-base regulation during short-term hypercapnia is effective in a shallowwater crab, but ineffective in a deep-sea crab. Mar Ecol Prog Ser 334:1-9

Paul AJ, Fuji A (1989) Bioenergetics of the Alaskan crab Chionoecetes bairdi (Decapoda: Majidae). J Crustac Biol 9:25-36

$>$ Pequeux A (1995) Osmotic regulation in crustaceans. J Crustac Biol 15:1-60 
Pörtner HO, Langenbuch M, Reipschlager A (2004) Biological impact of elevated ocean $\mathrm{CO}_{2}$ concentrations: lessons from animal physiology and earth history. J Oceanogr 60: 705-718

Rees BB, Hand SC (1990) Heat dissipation, gas exchange and acid-base status in the land snail Oreohelix during shortterm estivation. J Exp Biol 152:77-92

Seibel BA, Walsh PJ (2001) Potential impacts of $\mathrm{CO}_{2}$ injection on deep-sea biota. Science 294:319-320

Seibel BA, Walsh PJ (2003) Biological impacts of deep-sea carbon dioxide injection inferred from indices of physiological performance. J Exp Biol 206:641-650

Seibel BA, Thuesen EV, Childress JJ, Gorodezky LA (1997) Decline in pelagic cephalopod metabolism with habitat

Editorial responsibility: Josep-Maria Gili,

Barcelona, Spain depth reflects differences in locomotory efficiency. Biol Bull 192:262-278

Soltoff SP, Mandel LJ (1983) Amiloride directly inhibits the $\mathrm{Na}, \mathrm{K}$-ATPase activity of rabbit kidney proximal tubules. Science 220:957-958

Walsh PJ, Henry RP (1990) Activities of metabolic enzymes in the deep-water crabs Chaceon fenneri and C. quinquedens and the shallow-water crab Callinectes sapidus. Mar Biol 106:343-346

Wheatly MG, Henry RP (1992) Extracellular and intracellular acid-base regulation in crustaceans. J Exp Zool 263: $127-142$

Zar JH (1984) Biostatistical analysis. Prentice-Hall Inc, Englewood Cliffs, NJ

Submitted: March 26, 2008; Accepted: September 4, 2008

Proofs received from author(s): October 3, 2008 